\title{
BANGUNAN PEMBENTUKAN TEORI KONSTRUKSI SOSIAL PETER L BERGER: TEORI PEMBEDAH REALITAS GANDA KEHIDUPAN MANUSIA
}

\author{
Nurkhalis ${ }^{1)}$ \\ ${ }^{1}$ Prodi Sosiologi, Fakultas Ilmu Sosial dan Ilmu Politik \\ Universitas Teuku Umar \\ email:nurkhalis@utu.ac.id
}

\begin{abstract}
This article examines two realities of life experienced by humans in living. These two realities are subjective and objective, both of which have a high power of study when combined. As the development of phenomena or social problems increasingly complex, the presence of Social Construction theory becomes a bridge to see the social situation in the two sides of the subjective and objective. As the sociologists struggle arguing for subjective and objective dominance, the Social Construction theory takes its position as peacemaker by giving portions on both sides that are equally important. Therefore, it is appropriate that the Social Construction theory is categorized into the critical theory of a set of tools closer to the social reality for observing the social dynamic and social static.
\end{abstract}

Keywords: Subjective, Objective, Social Construction theory, Social Dynamic, Social Static

\section{PENDAHULUAN}

Pemilihan seperangkat teori dalam penelitian subjektif-kualitatif maupun objektif-kuantitattif dirasakan perlu karena nantinya bisa dijadikan sebagai arahan atau pedoman peneliti untuk dapat mengungkapkan suatu fenomena agar lebih terfokus. ${ }^{1}$ Karakteristik yang menarik dari sebuah penelitian yang menggunakan pendekatan kualitatif maupun kuantitatif sebagai kemampuan untuk mendayahgunakan teori sebagai titik masuk untuk mendekatkan subjek pada realitas sosial yang ingin diteliti.

Dengan demikian, teori Konstruksi Sosial justru sebagai teori yang menjembatani antara teori kualitatif dan kuantitatif. Melalui teori nantinya subjektif serta objektif manusia dalam berkehidupan dikolaborasikan bersama untuk menemukan sisi

${ }^{1}$ Engkus Kuswarno, Metodologi Penelitian Komunikasi, Fenomenologi: Konsepsi, Pedoman dan Contoh Penelitian, (Bandung: Widya Padjadjaran, 2009), hal. 108 
Community: Volume 4, Nomor 1, April 2018

ISSN: 2477-5746

pengamatan manusia secara utuh sehingga segalanya tanpa luput diamati melalui tahapan penelitian akademisi.

\section{TINJAUANPUSTAKA}

Paradigma adalah suatu cara pandang untuk memahami kompleksitas dunia nyata. Darinya akan mempengaruhi pandangan mengenai fenomena, yakni teori. ${ }^{2}$ Terdapat beberapa pengungkapan paradigma dalam sosiologi sehingga mengisyaratkan kepada kita bahwa disiplin ilmu sosial memiliki pemikiran yang sangat beragam dalam pengintegrasian keilmuaan tersebut.

Berbagai paradigma yang akan tersebutkan nantinya, turut membawa perkenalan kepada ilmuwan penggagasnya, di antaranya William Purdue, George Ritzer, Margareth Poloma dan Jurgen Habermas. Keempat ilmuwan itu kiranya akan menjadi rujukan bagi peneliti mewakilkan beberapa paradigma yang memang banyak berseliweran dalam dunia pemikiran dalam ranah ilmu sosial.

Dimulai dari paradigma yang diusung Purdue. Dia membagi kedalaman atas penjabaran paradigma ke dalam tiga jenis, yakni paradigma order, paradigma plural, dan paradigma konflik. Lain halnya dengan Ritzer membaginya kedalam tiga bahagian dengan penyebutan berbeda, ialah paradigma definisi sosial, perilaku sosial dan fakta sosial. ${ }^{3}$ Selain itu, Margareth M. Poloma juga membagi kedalam tiga kategori, antara lain paradigma Naturalistik, paradigma Humanis dan paradigma Evaluatif. Sedangkan Jurgen Habermas, sebagai generasi ke-2 mazhab Frankfurt menentukan kedalam tiga pula, adalah paradigma Positivisme, paradigma Interpretatif dan paradigma Kritis.

Walaupun demikian, varian paradigma di atas tidak terlepas dari upaya ilmuwan menitikberatkan disiplin ilmunya kepada kajian-kajian (khusus) subjektif, objektif dan keterpaduan keduanya, subjektif-objektif. Oleh karena itu, dalam hal ini peneliti menegaskan untuk menggunakan paradigma yang menjadi acuan dari Jurgen Habermas terhadap paradigma interpretatif.

Sebagaimana pemahaman mendasarnya, bahwa interpretatif bermakna penafsiran yang memfokuskan pijakannya pada dimensi subjektif dalam suatu realitas sosial. Secara umum dapat dikatakan, bahwa interpreratif menjadi serangkaian usaha memandang ilmu sosial dengan penganalisaan secara sistematis dari melihat pada pelaku sosial yang menciptakan, memelihara dan mengelola dunia sosial mereka. Dengan kata lain interpretatif, menjadi jalan menafsirkan tindakan sosial individu atau kelompok yang melangsungkan interaksi dalam lingkungan kehidupan. Dalam hal ini,

\footnotetext{
${ }^{2}$ Deddy Mulyana, Metodologi Penelitian Kualitatif: Paradigma Baru Ilmu Komunikasi dan Ilmu Sosial Lainnya, (Bandung: Remaja Rosdakarya, 2004), hal. 9 dan 16

${ }^{3}$ George Ritzer, Sosiologi Ilmu Pengetahuan Berparadigma Ganda, (Jakarta: Rajawali Pers, 2011), hal. 9
} 
Interpretatif mencoba memahami tindakan sosial pada level makna -yang relatif, plural, dan dinamis.

Lebih jauh, pemberlakuan wacana keilmuan yang dibawa Habermas, senantiasa berupaya mengkonseptualisasikan subyek sebagai intersubjektf yang inheren ${ }^{4}$, dimana hubungan sosial yang terjadi dalam lingkup komunikasi bebas terhadap kekuasaannya. ${ }^{5}$

\section{Positivisme}

Positivisme muncul pada abad ke-19, yang dimotori oleh Augusst Comte atas karyanya, The Course Of Positive Philoshopy. Positivisme merupakan paradigma yang muncul paling awal dalam dunia ilmu pengetahuan. Keyakinan dasar aliran ini berakar pada paham ontologi realisme yang menyatakan bahwa realitas berada (exist) dalam kenyataan dan berjalan sesuai dengan hukum alam (natural laws). ${ }^{6}$

Sebagai seorang pencetus paradigma ini, Comte menyatakan bahwa secara garis bersar prinsip-prinsip Positivisme, yang hingga kini masih banyak digunakan dalam berbagai kesempatan pengembangan keilmuan. Namun, keberlanjutannya sehingga akhirnya paradigma menjadi rujukan bagi periset yang beraliran positivisme, bagian dari usaha kerja keras melalui pemikiran Emile Durkheim yang diuraikan secara jelas dalam karyanya Rules of The Sociology Methods. Menurut Durkheim, objek studi sosiologi adalah fakta social (social-fact).

Durkheim melalui fakta social, berupaya mengembangkan konsep masalah pokok sosiologi terpenting dan kemudian diujinya melalui studi empiris. Ia membayangkan bahwa fakta social adalah kekuatan (forces) dan struktur yang bersifat ekstenal dan memaksa individu. ${ }^{7}$ oleh karena itu kiranya, positivisme merupakan paradigma yang mengedepankan analisa untuk ilmu sosial memakai aturan konteks ilmu alam, adanya kecendrungan atas metode yang dianggap mampu mengorganisir Logika berpikir secara deduktif bersama dengan pengalaman empiris. Dan berupaya untuk memperoleh konfirmasi tentang hukum sebab-akibat yang biasa digunakan untuk memprediksi pola-pola umum gejala sosial tertentu.

Atas dasar pertimbangan di atas, maka secara metodologis, seorang periset dituntut untuk menggunakan metodologi eksperimen empiric atau metode lain yang setara. Hal ini dimaksudkan untuk menjamin agar temuan yang diperoleh betul-betul objektif dalam menggambarkan keadaan yang sebenarnya, mencari derajat presisi

\footnotetext{
${ }^{4}$ Lihat pada kata pengantar Arskal Salim \& Adlin Sila (ed), dalam buku berjudul, Serambi Mekkah yang Berubah: Views From Within, (Jakarta: Alvabet, 2012), hal. xxi

${ }^{5}$ Onong Uchjana Effendy, Ilmu, Teori dan Filsafat Komunikasi, (Bandung: Citra Aditya Bakti, 2003), hal. 406

${ }^{6}$ Agus Salim, Teori \& Paradigma Penelitian Sosial: Buku Sumber untuk Penelitian Kualitatif, (Yogyakarta, Tiara Wacana, 2006), hal.

${ }^{7}$ George Ritzer \& Douglass J. Goodman, Teori Sosiologi Modern, (Jakarta: Kencana, 2011), hal. 21
} 
Community: Volume 4, Nomor 1, April 2018

ISSN: 2477-5746

yang tinggi, melakukan pengukuran yang akurat, dan menguji hipotesis melalui analisa atas angka-angka yang berasal dari pengukuran. ${ }^{8}$

\section{Humanisme (Interpretatif)}

Perspektif etimologis dan historis dalam memahami makna kata humanism, menunjukkan bahwa inti persoalannya adalah adalah humanus atau manusia itu sendiri. Artinya bagaimana membentuk manusia (humanus) itu lebih manusiawi (melalui humanismus), serta pihak mana atau siapa yang bertanggung jawab dalam proses pembentukannya (humanista/ umanisti/ humanis). ${ }^{9}$ Bertolak jauh dari positivisme, yang lebih mengetengahkan keberadaan struktur yang lebih memaksa atau dalam bahasa ekstrem mengancam keberadaan individu. Hadirnya paradigma Humanisme (atau kita sebut saja interpretative) dalam hal ini lebih member ruang bagi tindakan manusia terhadap realitas sosial.

Dalam bahasa sederhana, yang coba peneliti simpulkan, bahwa paradigma interpretatif, merupakan bahagian dari cara yang memandang bahwa ilmu sosial sebagai analisis sistematis terhadap suatu makna tindakan sosial. Berupaya untuk memahami sekaligus menafsirkan bagaimana para pelaku sosial menciptakan dan memelihara atau mengelola dunia sosial mereka. Pada prinsip dasar penelitian, paradigma ini bersifat ganda, holistik pada hasil konstruksi pemikiran. Dan jika melihat pada cara pandang terhadap realitas sosial, maka paradigma ini mengorganisir logika berpikir secara induktif.

Pembahasan yang fokus pada sosiologi interpretatif ini, terlihat lebih terbatas pada berbagai masalah mikro-sosiologis. Dalam anggapannya bahwa, individu yang berinteraksi sebagai analisa yang tepat untuk menangkap suatu fenomena sosial dari realitas sosial di masyarakat nantinya. Para ilmuwan yang menggagas pondasi atas paradidgma interpretatif ini terdiri dari Max Weber, Wilham Dilthey, dan Alfred Schutz..

Max weber, pentingnya bagi seorang manusia dapat mendalami 'versthen', merupakan hal yang memberikan petunjuk atau pengamatan dan penafsiran teoritis terhadap kejiwaan subjektif manusia yang sedang dipelajari perilakunya atau dengan kata lain manusia mengedepankan empati untuk memahami perilaku yang sedang terjadi dalam suatu realitas masyarakat. ${ }^{10}$ Wilhiam Dilthey, yang mendasarkan keterampilan memahami pada bentuk-bentuk pemahaman yang telah ada dalam kehidupan sehari-hari, yang dibedakanya dalam tiga kelas 'ekpresi kehidpan': yakni ekpresi linguistic, ekpresi tindakan dan ekspresi nonverbal.11 Dan Alfredz Schutz,

\footnotetext{
${ }^{8}$ Opcit..., hal. 70

9 Bambang Sugiharto (ed), Humanisme dan Humaniora: Relevansinya bagi pendidikan, (Yogyakarta \& Bandung: Jalasutra, 2008), hal. 3-4

${ }^{10}$ Soerjono Soekanto, Max Weber: Konsep-konsep dasar dalam Sosiologi, (Jakarta: Rajawali Pers, 1985), hal. 10

${ }^{11}$ Thomas McCarthy, Teori Kritis: Jurgen Habermas, (Yogyakarta: Kreasi Wacana, 2011), hal. 90 dan 91
} 
menyatakan bahwa tindakan manusia adalah bagian dari posisinya dalam masyarakat ${ }^{12}$, yang berlangsung dengan pengalaman sehari-hari mereka. Dengan usaha Schutz yang akhirnya melanjutkan pelopor Fenomenologi Husserl-yang menerapkan fenomenologi dalam ilmu sosial. Sehingga akhirnya menjadikan keberlangsungan perkembangan munculnya teori lain dari rujukannya, di antaranya, Erving Goffman (Dramaturgi), Herbert Blumer (Interaksionisme Simbolik) Garfinkel (Etnometodologi) dan Peter Berger (dengan teori Konstruksi Sosialnya. Dari keseluruhan nama tersebut, mereka telah mencerdasi pengetahuan dengan dasar acuan pada paradigma interpretatif.

\section{Kritis}

Untuk dapat diketahui, bahwa yang menjadi keunggulan sekaligus menjadi nilai bergengsi dan terpenting dari teori-teori dalam paradigma kritis adalah kehadirannya sebagai ruang yang telah berhasil menawarkan cara pandang baru, keberpihakan dan daya kritis yang berbeda dari kedua paradigma sebelumnya: positivisme dan interpretatif. Maka sebagai seorang ilmuwan atau peneliti yang mempedomani paradigm ini, sebisa mungkin berusaha menjembatani sikapnya mengkritisi masyarakat dan juga mengajak masyarakat untuk dapat kritis pula. Sejatinya, adanya kesadaran bagi individu terlibat sebagai agen atau aktor perubahan sosial.

Kelahiran teori kritis sebagai bagian dari pemikiran Neo-Marxis dipengaruhi dan terkait dengan beberapa konsep kritik Kant, Hegel, Marx dan Freud. Secara lebih jelas bahwa, teori kritis adalah produk dari para pemikir Neo-Marxis Jerman yang mulai menyadari keterbatasan teori Marxian dalam memahami perubahan realitas sosial yang semakin kompleks di era masyarakat modern dan post-modern. ${ }^{13}$ Pada tataran kritik dalam pengertian Marx adalah usaha untuk mengemansipasi diri manusia dengan berbagai bentuk penindasan dan munculnya alienasi terhadap individu atau sekolompok golongan tertentu yang dihasilkan oleh hubunganhubungan kekuasaan dalam masyarakat.

Berbicara perihal mengejawantahkan paradigma kritis dalam keilmuan di dunia ini, alangkah baiknya jika kita memulai kemunculannya dari Frankfurt School. Dimana keberadaan dari Frankfurt School telah menghadirkan kumpulan generasi yang bernaung dalam Mazhab Frankfurt, yang hampir keseluruhan mereka antusias mempergunakan teori kritis, yang alirannya tentulah berasal dari paradigma kritis. Tidak ada salahnya agar semakin memperjelas tentang paradigma ini, sebaiknya kita merujuk langsung kepada generasi kedua, yakni Jurgen Habermas. Dia merupakan

\footnotetext{
${ }^{12}$ Engkus Kuswarno, Metodologi Penelitian Komunikasi Fenomenologi: Konsepsi, Pedoman dan Contoh Penelitiannya, (Bandung: Widya Padjadjaran, 2009), hal. 38

13 Dalam buku Bagong Suyanto, yang mengetengahkan bahasan tentang Perspektif Teori Kritis: Kerangka Teori, dari karyanya sendiri berjudul Anak Perempuan Yang Dilacurkan: Korban Eksploitasi di Industri Seksusal Komersial, (Yogyakarta: Graha Ilmu, 2012), hal. 18
} 
Community: Volume 4, Nomor 1, April 2018

ISSN: 2477-5746

ilmuwan yang tanpa keraguan dan mengukuhkan posisi teori kritis di era postmodernitas, berbeda hal dengan penggagasnya Adorno dan Horkheimer yang telah ragu dan tidak kuasa melanjutkan kebertahanannya.

Jurgen Habermas bukan sekedar teoritisi sosial unggul yang dapat diperdebatkan, namun dia juga pembela modernitas dan rasionalitas yang utama dalam menghadapi serangan atas ide-ide modernitas oleh kaum postmodernis. ${ }^{14}$ Dalam penjelasan dan analisis yang dikemukakan, teori kritis diakui berhasil menawarkan cara pandang yang sangat potensial lebih berguna dan secara politis lebih relevan, di antaranya, pertama, teori kritis mengajukan konsepsi mengenai teori normatif dan kritis yang dialihkan untuk pembebasan, kebahagiaan, dan pengaturan masyarakat secara rasional. Kedua, berusaha mendapatkan hubungan dengan analisa empirik mengenai dunia kontemporer dan pergerakan-pergerakan sosial yang berusaha mentranformasikan masyarakat dalam cara-cara yang progresif. 15

Sejalan dengan paradigma pemikiran Habermas, yang dalam hal ini dipilih paradigma yang ditetapkannya menduduki urutan pertama, ialah paradigma interpretatif. Oleh karena itu, tepat rasanya jika dalam penelitian ini menggunakan teori utama dalam penganalisaan yang mengacu pada teori Konstruksi sosial, mengingat teori tersebut digolongkan dalam paradigm interpretatif. Teori konstruksi sosial memandang bahwa realitas sosial berlangsung dengan tiga momen dialektis, masyarakat sebagai produk manusia, masyarakat merupakan realitas objektif dan manusia adalah produk masyarakat.

Tabel 3.1 Paradigma dalam Ilmu-ilmu Sosial

\begin{tabular}{|c|c|c|c|}
\hline 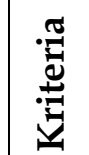 & Positivisme & Interpretatif & Kritis \\
\hline
\end{tabular}

\footnotetext{
${ }^{14}$ George Ritzer, Teori Sosial Postmodern, (Yogyakarta: Kreasi Wacana, 2008), hal. 254

${ }^{15}$ Opcit..., hal. 19
} 


\begin{tabular}{|c|c|c|c|}
\hline 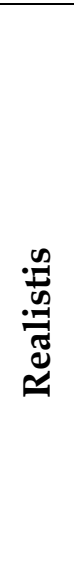 & $\begin{array}{l}\text { - Objektif } \\
\text { - Dipersepsikan } \\
\text { melalui indera } \\
\text { - Diatur oleh hukum- } \\
\text { hukum universal } \\
\text { - Terintegrasi dengan } \\
\text { baik demi kebaikan } \\
\text { semua } \\
\text { - Mengatur segalanya } \\
\text { dalam acuan } \\
\text { keteraturan }\end{array}$ & $\begin{array}{l}\text { - Subjektif } \\
\text { - Diciptakan, bukan } \\
\text { ditemukan } \\
\text { - Didayahgunakan secara } \\
\text { kreatif dan bebas }\end{array}$ & $\begin{array}{l}\text { - Penengah antara } \\
\text { antara subjektif dan } \\
\text { objektif } \\
\text { - Berada dalam } \\
\text { ketegangan, penuh } \\
\text { kontradiksi } \\
\text { - Menjadi dasar acuan } \\
\text { terpadu atau alternatif } \\
\text { khusus }\end{array}$ \\
\hline 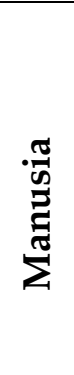 & $\begin{array}{l}\text { - Individu rasional } \\
\text { - Tidak memiliki } \\
\text { kebebasan } \\
\text { berkehendak } \\
\text { - Penuh aturan } \\
\text { sistematis yang harus } \\
\text { diikuti }\end{array}$ & $\begin{array}{l}\text { - Pencipta dunia } \\
\text { - Memberikan arti pada } \\
\text { dunia } \\
\text { - Menciptakan rangkaian } \\
\text { makna } \\
\text { - Berpedoman dari bahasa } \\
\text { dan tindakan }\end{array}$ & $\begin{array}{l}\text { - Dinamis pencipta } \\
\text { nasib } \\
\text { - Dihalangi oleh } \\
\text { realisasi secara penuh } \\
\text { - Pendobrak atau } \\
\text { pencerah dari keadaan }\end{array}$ \\
\hline 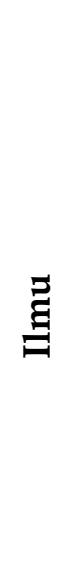 & $\begin{array}{l}\text { - Didasarkan pada } \\
\text { hukum dan prosedur } \\
\text { ketat } \\
\text { - Deduktif } \\
\text { - Bebas nilai } \\
\text { - Terpaku dengan pola } \\
\text { struktur yang } \\
\text { berkuasa }\end{array}$ & $\begin{array}{l}\text { - Didasari pengetahuan } \\
\text { sehari-hari } \\
\text { - Induktif } \\
\text { - Didasarkan pada } \\
\text { interpretasi } \\
\text { - Tidak bebas nilai } \\
\text { - Subjektif yang menjadi } \\
\text { focus utama }\end{array}$ & $\begin{array}{l}\text { - Membebaskan dan } \\
\text { memampukan } \\
\text { - Menjelaskan } \\
\text { dinamika-dinamika } \\
\text { system yang tercipta } \\
\text { - Tidak bebas nilai } \\
\text { - Mampu mengontrol } \\
\text { secara pribadi } \\
\text { - Merestrukturasi } \\
\text { masyarakat secara } \\
\text { emansipatoris }\end{array}$ \\
\hline
\end{tabular}


Community: Volume 4, Nomor 1, April 2018

ISSN: 2477-5746

\begin{tabular}{|c|c|c|c|}
\hline 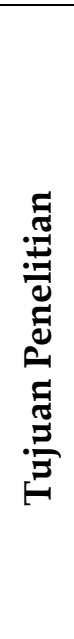 & $\begin{array}{l}\text { - Menjelaskan antara } \\
\text { sebab dan akibat } \\
\text { realitas sosial } \\
\text { - Menekankan fakta } \\
\text { (objektif) } \\
\text { - Terkungkung dengan } \\
\text { hipotesis yang } \\
\text { mengawali }\end{array}$ & $\begin{array}{l}\text { - Menginterpretasikan } \\
\text { dunia } \\
\text { - Menekankan makna } \\
\text { - Menyimpulkan } \\
\text { pemahaman atas bahasa } \\
\text { dan tindakan }\end{array}$ & $\begin{array}{l}\text { - Mengungkap yang } \\
\text { dibalik permukaan } \\
\text { - Mengungkap mitos } \\
\text { dan ilusi } \\
\text { - Menekankan } \\
\text { pembebasan, } \\
\text { pemampuan } \\
\text { - Menemukan dan } \\
\text { menjelajahi secara } \\
\text { lebih komprehensif } \\
\text { dan memiliki } \\
\text { mutualitas tinggi }\end{array}$ \\
\hline
\end{tabular}

Sumber; E Kristi Poerwandari, Pendekatan Kualitatif dalam penelitian Psikologi, (Jakarta: LPSP3, 1994), hal. 19-21, Agus Salim, Teori \& Paradigma Penelitian Sosial: Buku Sumber Untuk Penelitian Kualitatif, (Yogyakarta: Tiara Wacana, 2006), hal. 6, ditambah adaptasi penulis.

\section{METODE PENELITIAN}

Penelitian ini menggunakan pendekatan kualiatif secara deskriptif ${ }^{16}$. Peneliti dengan bebas mengamati objeknya ${ }^{17}$, menjelajah, dan menemukan wawasan-wawasan baru sepanjang jalan. ${ }^{18}$ atau dengan kata lain, data dari penelitian kualitatif itu nantinya, datanya berasal dari kondisi obyek yang alamiah-dimana peneliti adalah instrumen kunci, teknik pengumpulan data dilakukan secara triangulasi. Analisa data bersifat induktif, dan hasil penelitian kualitatif lebih mendalam makna daripada generalisasi. ${ }^{19}$

Pada penelitian ini sumber penguatan data menggunakan data sekunder meliputi bahan bacaan buku, skripsi sebagai bahan penguatan penganalisasan untuk mengupas secara mendetail dan mendalam terkait dengan bangunan terbentuknya teori konstruksi sosial sebagai teori pembedah realitas ganda kehidupan manusia bermasyarakat.

\footnotetext{
${ }^{16}$ Pemahaman deskiptif yang dimaksudkan nantinya,penelitian terus menerus mengalami reformulasi dan redireksi ketika informasi-informasi baru ditemukan. Hipotesis tidak datang sebelum penelitian tetapi hipotesis akan muncul dalam penelitian, periksa Nina W. Syam, Sosiologi Komunikasi, (Bandung: Humaniora, 2009), hal. 232

${ }^{17}$ E Kristi Poerwandari, Pendekatan Kualitatif dalam penelitian Psikologi, (Jakarta: LPSP3, 1994), hal. 9

${ }^{18}$ Jalaluddin Rakhmat, Metode Penelitian Komunikasi, (Bandung, Remaja Rosdakarya, 1985), hal. 36

${ }^{19}$ Sugiyono, Memahami Penelitian Kualitatif, (Bandung: Alfabeta, 2007), hal. 1
} 


\section{TEMUAN DAN PEMBAHASAN}

Dalam perjalanan keilmuannya, Peter Berger banyak mengadopsi dasar pemikirannya yang berasal dari gurunya yakni Alfred Schutz. Sang guru berjasa sebagai pengagas yang mengangkat fenomenologi untuk dijadikan sebuah bahagian teori untuk pengungkapkan fenomena-fenomena yang tersembunyi di sekitar manusia. Sebelumnya perlu dalam hal ini, mengetahui keterhubungan atau keterikatan yang pada akhirnya menghasilkan teori konstruksi sosial.

Kata kunci secara khusus memahami pemikiran Berger, bahwasanya, apa yang dihasilkannya melalui teori konstruksi sosial merupakan perpanjangan tangan dari teori fenomenologi. Ketika pada awalnya mulanya dunia dilingkupi kehadiran teori yang dalam paradigma fakta sosial maka atas gagasan Emile Durkheim, dan kemudian adanya teori yang dicetus oleh Berger menjadi salah satu teori yang berporos pada paradigm definisi sosial. Lebih tegasnya, teori dari konstruksi berupaya menyandingkan bahkan bisa dinyatakan dalam hal ini mempertandingan teorinya dengan teori-teori yang berada pada level makro saat membicarakan masyarakat.

Dalam penjelasan atas paradigma fakta sosial, lebih didominasi dengan teori struktural fungsional mengetengahkan peran struktur yang akan selalu saja mempengaruhi perilaku masyarakat serta menekankan kepada keteraturan (order) dan mengabaikan konflik dan perubahan-perubahan dalam masyarakat. ${ }^{20} \mathrm{Dan}$ di sisi lain, bersumber dari paradigm definisi sosial yang fokus mengentengahkan teori tindakan, dimana posisi aktor yang memiliki kemampuan untuk menentukan tindakan dalam posisi masyarakat.

Manusia memiliki kebebasan untuk mengekspresikan dirinya tanpa terkait dengan struktur dimana ia berada. Manusia memiliki subjektivitasnya sendiri. Manusia adalah agen bagi dirinya sendiri, artinya pada arena subjektivitas pada diri inidividu ketika individu tersebut mengambil tindakan di dalam dunia sosial melalui kesadarannya. ${ }^{21}$ Kendati demikian, konstruksi yang dilakukan manusia, dengan tindakan mereka tergantung pada pemahaman dan pemberian makna pada tindakan tersebut.

\section{Teori Fenomenologi Alfred Schutz}

Alfred Schutz yang menjadi acuan Berger mendalami kajian ilmu tentang fenomenologi. Sebelumnya Schutz memperoleh ilmu tersebut berasal dari pelopornya yaitu Husserl.Menurut Husserl, dengan fenomenologi kita dapat mempelajari bentukbentuk pengalaman dari sudut pandang orang yang mengalaminya secara langsung, seolah-olah kita mengalaminya sendiri. Fenomenologi tidak saja mengklasifikasikan setiap tindakan sadar yang dilakukan, namun juga meliputi prediksi terhadap

\footnotetext{
${ }^{20}$ George Ritzer, Sosiologi Ilmu Pengetahuan Berparadigma Ganda, (Jakarta: RajaGrafindo Persada, 2011), hal. 21

${ }^{21}$ Nur Syam, Islam Pesisir, (Yogyakarta: LKiS, 2005), hal. 35
} 
Community: Volume 4, Nomor 1, April 2018

ISSN: 2477-5746

tindakan di masa yang akan datang (because-motive), dilihat dari aspek-aspek yang terkait dengannya. Semua itu bersumber dari bagaimana seseorang memaknai objek dalam pengalamannya. Oleh karena itu tidak salah apabila fenomenologi juga diartikan sebagai studi tentang makna, di mana makna itu lebih luas dari sekedar bahasa yang mewakilinya. 22

Masih dalam bahasan kajian fenomenologi yang digagas Husserl, pada awal mulanya konsep fenomenologi yang dibawanya masih bersifat samar dan juga masih terselimuti oleh ide-ide yang masih kabur. ${ }^{23}$ Selanjutnya ditangan Schutzlah dari tipe fenomenologi yang digagaskan, yaitu fenomenologi transedental, maka bagian ini mejadi titik tolak yang kemudian melangkahkan Schutz jauh pada ranah fenomenologinya tersendiri24, dan mengukuhkan fenomenologi sebagai kajian yang patut diperhitungkan dalam sosiologi.

Dalam kaitannya dengan fenomenologi, bagi Schutz, tugas utama analisis fenomenologis adalah merekonstruksi dunia kehidupanmanusia 'sebenarnya' dalam bentuk yang mereka sendiri alami. Realitas dunia tersebut bersifat intersubjektif dalam arti bahwa anggota masyarakat menterjemahkan atau menginterpretasikan tentang dunia yang mereka internalisasikan melalui sosialisasi sehingga memungkinkan mereka melakukan interaksi maupun komunikasi. ${ }^{25}$ Dari pandangan tersebut jelas tampak adanya persamaan antara Schutz dan Weber dari persoalan pemahaman. Selain itu, bukan berarti justru tidak ada perbedan antara keduanya. Kiranya ada sedikit saja ketidaksamaan, dimana Weber memaknai tindakan identik dengan motif untuk tindakan yang diartikan bahwa untuk dapat memahami tindakan individu haruslah dilihat dari motif apa yang mendasari tindakan itu (in-order-to-motive). Sedangkan Schutz di samping meletakkan tindakan identik dari motif atas tindakan,

\footnotetext{
${ }^{22}$ Opcit..., hal. 10

${ }^{23}$ Irving M. Zeitlen, Memahami Kembali Sosiologi: Kritik Terhadap Teori Sosiologi Kontemporer, (Yogyakarta: Gadjah Mada University Press, 1995), hal. 207

${ }^{24}$ Setidaknya terdapat empat fenomenologi dalam lingkup teori-teori sosial, yaitu pertama, fenomenologi realistis,dipelopori oleh Alexander Pfander, Herbert Spielberg, et.al, menekankan pencarian pada persoalan universal manusia ditinjau dari berbagai objek, yang meliputi tindakan, motif tindakan, serta nilai kepribadian. Kedua, fenomenologi konstitutif atau disebut juga fenomenologi transedental yang dimiliki Husserl, dimana seluruh aktivitas subjek adalah menciptakan dunia. Tetapi Husserl tidak menjelaskan bahwa dalam kehidupannya yang sesungguhnya akan dipengaruhi tindakan subjek oleh motif in-order-to-motive (masa yang lalu). Selanjutnya fenomenologi hermeneutik dari Gadamer dan Ricour dengan fokus pada kajian mengenai sifat linguistic manusia. serta fenomenologi eksistensial Schutz dengan terfokus menganalisa dunia kehidupan. Ketika bahasan ini menetapkan pada fenomenologi eksistensial itu sendiri, maka pemaknaan dari makna eksistensisal di sini kiranya sepaham dengan apa yang coba diungkapkan Frans Magnis Suseno tentang kebebasan, bahwa eksistensial berkenaan dengan kemampuan seseorang untuk menentukan tindakan sendiri, periksa tulisan Gutheng Prabowo berjudul Fenomenologi dalam buku Agus Salim, Teori \& Paradigma Penelitian Sosial: Buku Sumber untuk Penelitian Kualitatif, (Yogyakarta: Tiara Wacana, 2006), 171-173, periksa Nur Syam, Islam Pesisir, (Yogyakarta: LKiS, 2005), 36, dan periksa juga Frans Magnis-Suseno, Etika Dasar, (Yogyakarta: Kanisius, 1987), 22

${ }^{25}$ Dedy Mulyana, Metodologi Penelitian Kualitatif: Paradigma Baru Ilmu Komunikasi dan Ilmu Sosial lainnya, (Bandung: Remaja Rosdakarya, 2001), hal. 63
} 
selanjutnya ada penambahan dengan motif asli yang mendasari tindakan yang dilakukan oleh individu (because-motive). ${ }^{26}$

\section{Teori Tindakan Sosial Weber}

Dalam perkembangan pemikiran Weber, ada empat jenis tindakan sosial yang akan mempengaruhi struktur sosial masyarakat. Adapun keempat jenis tindakan tersebut di antaranya,

1) Rasional instrumental (Zwerk rational), yakni tindakan social yang dilakukan seseorang didasarkan pada pertimbangan dan pilihan sadar yang berhubungan dengan tujuan tindakan itu dan ketersediaan alat yang dipergunakan untuk mencapainya.

2) Tindakan yang berorientasi pada nilai (Werktrational action). Tipe tindakan ini menyatakan bahwa aktor tidak dapat menilai apakah cara-cara yang dipilihnya itu merupakan yang paling tepat ataukah lebih tepat untuk mencapai tujuan yang lain atau dengan ungkapan lain nilai akhir bagi individu yang bersifat nonrasional sehingga tidak memperhitungkan alternatif.

3) Tindakan Afektif (Affectual action). Tindakan yang sengaja dibentuk dengan kendali emosi dan kepuraan si-aktor. Dengan bahasa lain, tindakan yang didominasi perasaan atau emosi tanpa refleksi intelektual atau perencanaam sadar.

4) Tindakan tradisional (Traditional action). Tindakan yang didasarkan pada kebiasaan-kebiasaan dalam mengerjakan sesuatu di masa lalu. ${ }^{27}$

Dari perjalanan sejarah kemunculannya yang tersebut di atas, Peter Berger yang turut diperbantukan bersama Thomas Luckmann melahirkan teori konstruksi sosial. Sebenarnya kedua ilmuwan yang hadir dengan disiplin ilmu yang berbeda; Peter Berger berasal dari keilmuwan sosial dan Thomas Luckmann yang dari ilmu filsafat. ${ }^{28}$ Dari sintesa pertemuan dasar keilmuan keduanya tersebutlah teori konstruksi sosial yang membawa pada kajian tentang sosiologi pengetahuan.

Dalam usaha mereka menjelaskan bagaimana cara terkonstruksi sosialnya, maka ada dua hal yang mendasari, pertama, tentang 'kenyataan sosial' dan kedua, berkaitan dengan pengetahuan. Adapun yang dimaksud dengan kenyataan sosial, adalah bagaimana sesuatu yang tersampaikan dalam pergaulan sosial melalui komunikasi secara bahasa dan tindakan. Dalam hal tersebutt, berlaku ketentuan bahwa, kenyataan sosial sebagai kenyataan yang ganda.

\footnotetext{
${ }^{26}$ Opcit...., hal. 36

${ }^{27}$ Dalam tulisan berjudul Interaksi dan Tindakan Sosial,karya Bagong Suyanto dan Septi Ariadi dalam buku J. Dwi Narwoko dan Bagong Suyanto (ed), Sosiolog: Teks Pengantar dan Terapan, (Jakarta: Kencana, 2010), hal. 19

${ }_{28}$ Bagong Suyanto dan M. Khusna Amal (ed), Anatomi dan Perkembangan Teori Sosial, (Malang, Yogyakarta: Aditya Media Publishing, 2010), hal. 143
} 
Community: Volume 4, Nomor 1, April 2018

ISSN: 2477-5746

\section{Teori Interaksi Simbolik Mead}

Selanjutnya, dari kenyataan sosial tersebut berlangsung dalam pengalaman intersubjektif, adanya kenyataam dalam kehidupan sehari-hari yang memiliki dimensi objektif dan subjektif. Pertemuan antara di satu bagian menjadi pencipta masyarakat dan sebaliknya terpengaruhi masyarakat yang akan menciptakan manusia. Sedangkan pengetahuan, dipahami sebagai kenyataan sosial yang akan menghayati kehidupan bermasyarakat dengan segala aspeknya meliputi kognitif, psikomotorik, emosional dan intuitif. Dalam arti yang lain, keadaan diri (subjektif) memilih untuk mencocokkan apa yang dianggapnya sebagai suatu hal pembenaran tetapi masih dalam proses pemilihan dari pengalaman dunia sosio-kultural.Oleh karena itu, semula telah mampu dilihat adanya dimensi objektif dan subjektif yang saling terkait di dalam pemikiran Berger.

\section{Teori Struktur Sosial Durkheim}

Asal mula pandangan Berger, bahwa manusia yang hadir dalam dunia sosiokultural, akan membawa diri pada pelibatan dimensi obyektif yang bagian ini diperoleh dari cara berpikirnya Durkheim. Sedangkan untuk pelibatan dalam dimensi subjektif, acuan berpikir yang dipeoleh dari kajian Weber mengenai subjektivitas. Walaupun kedua ilmuwan acuan Berger, melihat pada konsep masing-masing yang dinyatakan keberadaan secara terpisah jauh. Namun, dengan keputusan Berger atas keilmuan menyatakan bahwa keduanya menjadi bagian yang tidak bisa terpisahkan satu samalain. Tidak mampu dipungkiri bahwa manusia di dalam masyarakat akan melewati dimensi kedua dalam bertindak terhadap lingkungan mereka.

Masyarakat yang dikatakan merupakan bahagian dari kenyataan objektif secara bersama melibatkan kenyataan subjektif di dalamnya. Apa yang dipahami dengan kenyataan objektif, dimana masyarakat seperti berada terlepas (di luar) dari diri manusia dan saling bertaut antara keduanya. Berbeda halnya dengan, kenyataan subjektif langsung akan berada di dalam masyarakat menjadi bahagian yang menyatu (tidak terpisahkan). Bisa diungkapkan secara singkat, bahwa satu sisi masyarakat sebagai bagian dari produk masyarakat dan di sisi lain justru manusia sebagai produk masyarakat. ${ }^{29}$

Berangkat dari sentuhan Hegel, yaitu tesis, anti tesis dan sintesis. Berger menemukan konsep yang menyatakan penghubung antara subjektif dan objektif itu melalui apa yang disebut dengan dialektika. Memahami 'dialektika' adalah istilah yang sering digunakan dalam berbagai arti yang berbeda. Namun, kita mencoba menelusuri sebuah istilah yang sepadan dengan sentuhan Hegel di alam berpikir Berger atas keilmuannya. Dialektika yang dimaksud ialah satu pemukiran kita tentang dunia yang akan mengalami tiga tahapan tahapan; tesis, anti tesis dan sintesis. Dalam

\footnotetext{
${ }^{29}$ Margareth Poloma, Sosiologi Kontemporer, (Jakarta: RajaGrafindo Persada, 2010), hal. 302
} 
satu terminologi yang berbeda, tapi pada dasarnya sama, dengan menyebut ketiga tahapan itu dengan posisi, posisi negasi, negasi dari negasi. ${ }^{30}$

Melanjutkan konsepsi dialektika Hegel, maka Berger mencoba menjabarkan konsepsi dialektika dari teorinya yang dikenal dengan eksternalisasi, objektivasi, internalisasi. Adapun yang dimaksud dengan keseluruhan dari tiga momen dialektika tersebut yakni, eksternalisasi, proses yang menarik individu keluar untuk melakukan penyesuaian diri terkesan bahwa hal itu berada di luar (objektif). Pada objektivasi, dimana terjadi proses komunikasi intersubjektif di mana antarsubjek akan menyampaikan apa yang menjadi keinginannnya. Dan untuk internalisasi, proses penarikan kembali ke dalam diri atas masyarakat dipahami dengan proses pengindentifikasi individu dalam masyarakat. 31

Ketika akan memahami masyarakat sebagai realitas objektif (eksternalisasi). Eksternalisasi, yang sejalan dengan Durkheim dan tradisi kaum fungsionalisme struktural, Berger mengakui eksistensi realitas sosial objektif yang dapat dilihat dalam hubungannya dengan lembaga-lembaga sosial. ${ }^{2}$ Dalam bahasan yang lain, dalam kehidupan memiliki aturan dan hokum-hukum yang menjadi pedoman dari berbagai institusi-institusi sosial. Tatkala aturan itu telah menjadi parameter bagi manusia dalam masyarakat, akan meminta adanya pencapaian pada keteraturan sosial. Ketika hal ini menjadi perhitungan, sebagaimana lazimnya situasi kondisi yang kadangkala mengekang manusia dalam bertindak, tanpa disangka-sangka juga menimbulkan pelanggaran. Kendati demikian, adanya dua penggolongan individu, yang satu mengedepankan ketertiban sosial sejatinya akan menyesuaikan diri dengan aturan yang ada. Dan yang satunya, keadaan yang lebih menginginkan penolakan diri dengan upaya ketidaksesuain diri untuk menyesuaikan diri dengan aturan sosial yang telah terinstitualisasi.

Pada masyarakat yang mengalami suatu kenyataan objektif, apa yang mendasari dari sehingga terbentuknya suatu institusionalisasi disebabkan adanya dua pemicu, pertama, dengan pembiasaan (habiatualisasi) dan kedua, dengan legitimasi. Secara jelas dinyatakan, habiatualisasi mengenai bagian dari kegiatan manusia yang mengalami proses pembiasaan. Dalam kemunculannya, bermula dari pembiasaan yang dirasakan telah menyebabkan individu tidak perlu lagi untuk mendefinisikan kembaliapa yang telah dijadikan pembenaran (dari atau dengan pengalaman). Ketika habiatualisasi telah sempurna terjadi, selanjutnya menghadirkan pengendapapan dan tradisi. Segala pengalaman pun akan terformat seketika untuk kemudian menjadi 'warisan' yang diikuti oleh generasi mendatang dengan cara yang sama dan dengan upaya yang sama ekonomisnya.Seruntutan dari habiatualisasi terdiri atas bahasa dan

\footnotetext{
${ }^{30}$ John Elster, Karl Marx: Marxisme-Analisis Kritis, (Jakarta: Prestasi Pustakaraya, 2000), hal. 48

${ }^{31}$ Disertasi Nur Syam: Tradisi Islam Lokal Pesisir (Studi Konstruksi Sosial Upacara pada Masyarakat Pesisir Palang, Tuban Jawa Timur), mahasiswa pascasarjana Universitas Airlangga, Surabaya, 2003) hal. 45-46

${ }^{32}$ Opcit..., hal. 302
} 
tindakan yang dilangsungkan oleh indididu dalam masyarakat. Sebagai sebuah percontohan untuk bertindak yang akan terhubung dengan orang lain.

Berlanjut kepada legitimasi, dalam hubungannya dengan konstruksi sosial, agama telah merupakan sumber legitimasi yang paling efektif dan meluas. ${ }^{33}$ sebagaibagian yang berkelinden dan berlanjut dari habiatualisasi. Apabila habiatualisasi telah menerima dengan pembiasaan atas pengalaman yang telah masuk ke dalam kesadaran yang terbenarkan. Maka legitimasi akan menyambungkan objektivasi yang sudah terlembagakan menjadi masuk akal secara subjektif.

Beralih kepada masyarakat sebagai kenyataan subjektif (internalisasi). Internalisasi merupakan tindakan untuk menjadikan manusia sebagai anggota suatu masyarakat. ${ }^{34}$ Melalui internalisasi, realitas objektif di luar manusia (sebagai institusi) menjadi realitas yang juga objektif di dalam manusia (sebagai bagian dari kesadaran). ${ }^{35} \mathrm{Apa}$ yang menjadi penguat dalam dimensi subjektif ini, adalah berlangsungnya sosialisasi yang dilangsungkan antarindividu dalam masyarakat. Atas sosialisasi tersebut terbagi dalam dua rincian, sosialisasi primer, yang dialami individu pada masa kecil (masa pra-sekolah dan masa sekolah) dan sosialisasi sekunder, dialami individu pada usia dewasa dan memasuki dunia publik, dunia pekerjaan, dalam lingkungan sosial yang lebih luas.

Selain itu pada Internalisasi, struktur menjadi bagian yang sebelumnya melewati Eksternalisasi dari proses Institusional sehingga pada akhirnya keadaaan itu akan menjadi pengaruh bagi individu melakukan internalisasi. Kemudian, lebih lanjut dalam Internalisasi itu pula mengutarakan apa yang dimaksud dengan teori-teori identitas yang kesamaan makna dengan teori-teori psikologi, memperhatikan secara seksama identitas apa dan bagaimana masih dipertahankan, modifikasi dan dilakukan pembentukan ulang dalam menghadapi dunia sosial interaksinya. Dan bagian lainnya yang menjadi perhatian Internalisasi dengan menguraikan kesimpulan bahwa manusia bersifat seperti organisme, yang akan terus saja dihadapkan untuk hidup dengan masyarakat lainnya dengan membawa identitas diri yang bisa mengintegrasikan dirinya di medan interaksi nantinya.

\section{KESIMPULAN}

Pemilihan dengan penggunaan teori konstruksi sosial yang dipelopori oleh Peter Berger dan Thomas Lukmann, menjadi bahagian dari teori yang meletakkan kedudukan mikro dan makro sebagai bagian yang resiprokal-tidak akan bisa dipisahkan satu sama lain. Namun, senada dari ungkapan sebelumnya, teori konstruksi social ini, lebih melihat keberadaan individu dengan kebebasan dan kreatifnya menghasilkan suatu produknya yaitu masyarakat, yang hal ini kiranya berkesesuaian dengan eksternalisasi, dimana suatu proses penyesuaian yang

\footnotetext{
${ }^{33}$ Loc cit..., hal. 309

${ }^{34} \log$ cit..., hal.304

${ }^{35}$ Opcit..., hal. 114
} 
dilakukan manusia dengan lingkungan. Di samping juga, terdapat internalisasi dan objektivasi dalam realitas sosial pada masyarakat, sehingga melengkapi bagiannya dan jangan sekali ilmuwan sebelumnya memperhatikan ketiga momen dialektis ini, yakni ekternalisasi, objektivasi dan internalisasi.

\section{DAFTARPUSTAKA}

\section{Buku}

Arskal Salim \& Adlin Sila (ed). 2012.Serambi Mekkah yang Berubah: Views From Within, (Jakarta: Alvabet.

Bagong Suyanto. 2012.Anak Perempuan Yang Dilacurkan: Korban Eksploitasi di Industri Seksusal Komersial. Yogyakarta: Graha Ilmu,

Bagong Suyanto dan M. Khusna Amal (ed). 2010. Anatomi dan Perkembangan Teori Sosial. Malang, Yogyakarta: Aditya Media Publishing.

Bambang Sugiharto (ed). 2008.Humanisme dan Humaniora: Relevansinya bagi pendidikan. Yogyakarta \& Bandung: Jalasutra.

Deddy Mulyana. 2004. Metodologi Penelitian Kualitatif: Paradigma Baru Ilmu Komunikasi dan Ilmu Sosial Lainnya. Bandung: Remaja Rosdakarya.

E Kristi Poerwandari. 1994.Pendekatan Kualitatif dalam penelitian Psikologi. Jakarta: LPSP3

Engkus Kuswarno. 2009. Metodologi Penelitian Komunikasi, Fenomenologi: Konsepsi, Pedoman dan Contoh Penelitian. Bandung: Widya Padjadjaran.

Frans Magnis-Suseno. 1987.Etika Dasar. Yogyakarta: Kanisius.

George Ritzer \& Douglass J. Goodman. 2011.Teori Sosiologi Modern. Jakarta: Kencana

George Ritzer. 2011. Sosiologi Ilmu Pengetahuan Berparadigma Ganda.Jakarta: Rajawali Pers.

2008.Teori Sosial Postmodern. Yogyakarta: Kreasi Wacana.

Irving M. Zeitlen. 1995.Memahami Kembali Sosiologi: Kritik Terhadap Teori Sosiologi Kontemporer. Yogyakarta: Gadjah Mada University Press. 
Community: Volume 4, Nomor 1, April 2018

ISSN: 2477-5746

J. Dwi Narwoko dan Bagong Suyanto (ed). 2010.Sosiolog: Teks Pengantar dan Terapan, (Jakarta: Kencana,

Jalaluddin Rakhmat. 1985.Metode Penelitian Komunikasi. Bandung: Remaja Rosdakarya.

John Elster. 2000.Karl Marx: Marxisme-Analisis Kritis. Jakarta: Prestasi Pustakaraya.

Onong Uchjana Effendy. 2003.Ilmu, Teori dan Filsafat Komunikasi. Bandung: Citra Aditya Bakti

Soerjono Soekanto. 1985.Max Weber: Konsep-konsep dasar dalam Sosiologi. Jakarta: Rajawali Pers.

Thomas McCarthy. 2011.Teori Kritis: Jurgen Habermas, (Yogyakarta: Kreasi Wacana,

Sugiyono. 2007.Memahami Penelitian Kualitatif, (Bandung: Alfabeta,

Margareth Poloma. 2010. Sosiologi Kontemporer. Jakarta: RajaGrafindo Persada.

\section{$\underline{\text { Penelitian }}$}

Disertasi Nur Syam. 2003.Tradisi Islam Lokal Pesisir (Studi Konstruksi Sosial Upacara pada Masyarakat Pesisir Palang, Tuban Jawa Timur. Surabaya: Mahasiswa pascasarjana Universitas Airlangga, Surabaya. 